\title{
CONTRIBUTION TO THE PHYTOCHEMICAL STUDY AND CHEMICAL TESTS OF THE EXTRACTS OF Citrus limonium (LEMON) and Capsicum frutescens L. (CHILLI PEPPER)
}

\author{
L. C. C. FREIRE, E. I. M. ARAUJO, F. I. S. P. VALDEVINO, F. F. M. SILVA, L. A. ALVES and L. M. BERTINI* \\ Instituto Federal do Rio Grande do Norte \\ luciana.bertini@ifrn.edu.br*
}

Article received September/2014 and accepted in February/2015

DOI: $10.15628 /$ holos.2015.2462

\section{ABSTRACT}

Use of natural medicine has been used by man since time immemorial, and this use has grown considerably in recent times. Thus, this study aims to make a comparator analysis regarding the phytochemical test, antioxidant activity and total phenolic content of the extracts of the leaves in ethanol and their respective fractions of Citrus limonium (lemon) and Capsicum frutescens L. (chilli pepper). To compare them was
\end{abstract}

observed that ethanol extract of both plants showed the better antioxidant activity, Capsicum frutescens L. with 204.60 ppm and 99.07 ppm with Citrus limonium. With regard to the phenolic content of the hexane extract and lemon extract in ethanol pepper were those that showed a higher content. Overall, it was noted that Citrus limonium excelled both in relation to their antioxidant activity and the phenolic content.

KEYWORDS: Citrus limonium, Capsicum frutescens L., Phytochemical test, Antioxidant activity, Total phenols.

\section{CONTRIBUIÇÃO AO ESTUDO FITOQUÍMICO E TESTES QUÍMICOS DOS EXTRATOS DE Citrus limonium (LIMÃO) e Capsicum frutescens L. (PIMENTA MALAGUETA)}

\section{RESUMO}

O uso de medicamentos naturais vem sendo utilizado pelo homem desde tempos imemoriais, e esse uso vem crescendo consideravelmente nos últimos tempos. Desta forma, o presente trabalho objetiva fazer uma análise comparatoria no que diz respeito a teste fitoquímico, atividade antioxidante e teor de fenóis totais dos extratos em etanol das folhas e suas respectivas frações de Citrus limonium (limão) e Capsicum frutescens L. (pimenta malagueta). Ao compara-las foi observado que extrato em etanol de ambas as plantas foi o que apresentou uma melhor atividade antioxidante, o Capsicum frutescens L. com 204,60 ppm e o Citrus limonium com 99,07 ppm. No que diz respeito ao teor de fenóis a fração em hexano do limão e o extrato em etanol da pimenta foram os que mostraram um teor mais alto. De forma geral, foi notado que o Citrus limonium se destacou tanto em relação a sua atividade antioxidante quanto ao teor de fenóis.

PALAVRAS-CHAVE: Citrus limonium, Capsicum frutescens L., Teste fitoquímico, Atividade antioxidante, Fenóis totais. 


\section{INTRODUCTION}

Thousands of years ago, several civilizations have started to use natural products in order to treat various diseases. Despite the big advances observed in modern medicine, the natural products continue to be used and $30 \%$ of all the drugs evaluated as therapeutical agents result of secondary metabolites (CALIXTO, 2005; VEIGA JUNIOR; MELLO, 2008).

The interest in natural products has become even bigger due to populations believing these do not cause any or cause few side effects, and that they apparently come out as effective where the traditional medicine has not presented the expected results, which is not always confirmed by the scientific researches that evaluate the effectiveness and safety, as well as the guarantee of the quality in the production (CALIXTO, 2005).

Many factors have estimulated the search for new drugs of vegetable origin, as for instance, the discovery of active drugs to fight cancer, the lack of access of the biggest part of the population to modern drugs, studies on biodiversity and the preservation of species (CARVALHO In:MERCADANTE et al, 2001).

The scientific field responsible for natural products has been putting a lot of effort in seeking substances that delay the aging of cells and thus prevent several diseases caused by this phenomenom; such substances are known as antioxidants.

The substances present in these natural sources that are able to act as antioxidants are minerals (mainly constituted by enzymes), vitamines and phenolic compounds. Amongst the most important under the technological point of few, we can name tocopherols, carotenoids, some organic acids such as citric acid and ascorbic acid, and the flavonoids. The extracts of citric fruits such as the lemon are important sources of phenolic acids, such as hydroxycinnamicacid and the flavonoids (flavanone and flavonols) (DIMITRIOS, 2006; ECONOMOS; CLAY, 1999).

The plants selected in order to carry out this study were the Capsicum frutescens L, popularly known as chilli pepper, classified in the family Solanaceae, gender Capsicum and the Citrus limonium, commonly known as lemon, classified in the family Rutaceae, gender Citrus.

The chilli pepper acts on the reduction of the level of fat in the blood, as spectorant, helping decongest the respiratory routes, as a reductor of inflamations and, by the content of vitamin C, as an antioxidant, being capable of contributing for the elimination of free radicals and, so being, slow down the aging process of the cells (REIFSCHNEIDER, 2000).

The family of Rutaceae presents around 150 genders and 1600 distributed around the tropical and sub-tropical regions of both hemispheres (BARROSO et al, 1986). In Brazil, there are 29 genders and 182 species (BARROSO et al, 1986). In phytotherapy, it is used to treat several pathologies such as reumatic, infections, fever, atherosclerosis, hemoglobin, scarring amongst others (MATOS, 2007)

So being, this paper aims to prepare extracts of the above-mentioned plants in order to determine the classes of secondary metabolites, the antioxidant activity and the content of total phenols, so as to achieve a better understanding of their abilities facing these properties. 


\section{MATERIAL AND METHODS}

\subsection{Collection of vegetable material}

The species of Capsicum frutescens $L$ and Citrus limonium have been collected in the city of Apodi, in Rio Grande do Norte. Both have been collected during a dry strike, in the morning, but the Citrus limonium has been collected in September 2011, while the Capsicum frutescens L was collected in January 2014. Out of Citrus limonium, we have only studies the leaves, while from Capsicum frutescens L., we have studied leaves, roots, branches and fruits.

\subsection{Preparation of the Extract in Ethanol}

The material was chopped and stored in a glass container with ethanol, being in contact for 7 days. After this period, the solvent in the leaves, branches, roots and fruits was filtered. Then, they were concentrated in a rotary evaporator system under reduced pressure in order to obtain the ethanol extracts.

\subsection{Fractioning of the Extract in ethanolic}

We have taken the extracts of $C$. frustescens and $C$. Limonium in ethanol and mixed them to silica gel in the proportion 1:1 by using mortar and pistil, making a homogenous mixture. There was made a process of vacuum filtering with three solvents in increasing order of polarity for this mixture: hexane, ethylacetate and methanol. After this process, the solvents were concentrated in a rotary evaporator under reduced pression in order to obtain the fractions if the given polarities.

\subsection{Phytochemical tests of the vegetable extracts}

The phytochemical tests have been carried out according to the methodology proposed by MATOS (2009). The extract in ethanol and the fractions of the extract in ethanol obtained from both plants have been submitted to tests of: phenols and tanines, flavonoids, catechins, steroids and triterpenes (Liberman-Buchard test) and saponins, as described in the following items:

\subsubsection{Test for Phenols and Tanines}

We have added 3 drops of alcoholic solution of $\mathrm{FeCl} 3$ and approximately $1 \mathrm{mg}$ of the extract in test tubes.After that, they were agitated and we have observed variations in the color and the formation of the precipitate.

\subsection{Test for Anthocyanins, Anthocyanidins and Flavanoids}

We have set aside three test tubes and added $1 \mathrm{mg}$ of extract to each.The first one was acidized to $\mathrm{pH} 3$, the second was alcalinized to $\mathrm{pH} 8.5$ and the third, to $\mathrm{pH} 11$. After that, we have observed the change in the color of the material and compared it in Table 1. 
Table 1: Evaluation of the colors for the tests of anthocyanins, anthocyanidins and flavonoids

\begin{tabular}{lccc}
\hline \multirow{2}{*}{ Constituents } & \multicolumn{3}{c}{ Natural color } \\
\cline { 2 - 4 } & Acid (pH 3) & Alcaline (pH 8.5) & Alcaline (pH 11) \\
\hline Anthocyanins and anthocyanidins & Red & Lilac & Crimson blue \\
\hline Flavones, Flavonols and Xanthones & - & - & Yellow \\
\hline Chaconnes and Aurons & Red & - & Crimson red \\
\hline Flavonols & - & - & Orange-red \\
\hline SOURCE: MATOS, 2009 & & &
\end{tabular}

\subsubsection{Test for Leucoanthocyadinin, Catechins and Flavones}

We have used two test tubes with extract, one of them acidized to $\mathrm{pH} 3$ and the second was alcalinized to $\mathrm{pH} \mathrm{11;} \mathrm{then,} \mathrm{the} \mathrm{tubes} \mathrm{were} \mathrm{heated} \mathrm{for} \mathrm{three} \mathrm{minutes} \mathrm{and} \mathrm{we} \mathrm{have} \mathrm{verified} \mathrm{the}$ variation in the color according to Table 2.

Table 2: Test for Leucoanthocyadinin, Catechins and Flavones

\begin{tabular}{lcc}
\hline \multirow{2}{*}{ Constituents } & \multicolumn{2}{c}{ Natural color } \\
\cline { 2 - 3 } & Acid & Alcaline \\
\hline Leucoanthocydins & Red & - \\
\hline Catechins (catechin tannins) & Grizzly-yellow & - \\
\hline Flavanones & - & Orange-red \\
\hline SOURCE: MATOS, 2009 & &
\end{tabular}

\subsubsection{Test for Flavanols, Flavanones, Flavanonols and Xanthones}

We have added to a test tube containing the extract a few centigrams of magnesium tape and $0.5 \mathrm{~mL}$ of concentrated $\mathrm{HCl}$. We have waited for the end of the reaction, indicated by the end of the effervescence and we have observed change in the color of the mixture. If the mixture remais slightly red, it indicates the positivity of the test.

\subsubsection{Test for Saponins}

We have added $5-10 \mathrm{~mL}$ of water to a test tube containing extract in order to dissolve it. After this process, the tube containing the solution was agitated strongly for two to three minutes, observing the formation of foam.

\subsubsection{Test for Steroids and Triterpenoids (Lieberman-Burchard)}

We have taken another test tube and added 1-2mL of chloroform in order to dissolute it. After this process, the solution in chloroform has been filtered in a small funnel closed with a small ball made of cotton into a second test tube. We have added $1 \mathrm{~mL}$ of acetic anhydrine and agitated softly, adding three drops of concentrated sulphuric acid $\left(\mathrm{H}_{2} \mathrm{SO}_{4}\right)$, agitating again and observing the behavior of the colors.

\subsection{Antioxidant Activity}

The tests to verify the antioxidant activity and find the concentration the inhibits $50 \%$ of the radicals $\left(\mathrm{Cl}_{50}\right)$ present in the extracts have been carried out with a DPPH solution (2,2diphenyl-1-pricrihydrazil) at $60 \mu \mathrm{M}$.We have prepared different concentrations with the extracts and mixed them at $1 \mathrm{~mL} \mathrm{DPPH}$, and after 30 minutes we have performed the readings of the 
spectrophotometer at 520nm (BRAND-WILLIAMS et al, 1995).Another procedure performed by the same means was done with TROLOX, positive pattern used for control. The results obtained after the reading were inserted in statistic software (Origin 7.0), so as a graphic would be generated, out of which we could calculate the $\mathrm{Cl}_{50}$ out of each sample.

\subsection{Content of Total Phenols}

The test for the verification of total phenols has been performed according to the method proposed by Folin-Cicalteau.Each vegetable extract has been dissolved into methanol and then transferred to a $100 \mathrm{~mL}$ volumetric flask and completed with more methanol. To another flask of $50 \mathrm{~mL}$, we have transferred $7.5 \mathrm{~mL}$ of the initial solution. The second solution has also had its volume completed with methanol. A $100 \mu \mathrm{L}$ aliquot of this last solution has been agitated with $500 \mu \mathrm{L}$ of the Folin-Ciocalteu reagent and $6 \mathrm{~mL}$ of destilled water for 1 minute; after that, we have added $2 \mathrm{~mL}$ of $\mathrm{Na}_{2} \mathrm{CO}_{3}$ at $15 \%$ to the mixture and agitated for 30 seconds. Then, we have added another $10 \mathrm{~mL}$ of destilled water. We have waited for two hours, and then the absorbance of the samples has been measured by the spectrophotometer at $750 \mathrm{~nm}$, by using a quartz cuvette (BONOLI et al, 2004). The quantification of the phenolic compounds in the extract was carried in triplicate and the results have been expressed in equivalents of gallic acid (GAE) by gram of gross extract.

\section{RESULTS AND DISCUSSIONS}

According to the methodology described on item 2.1, for the $C$. frutescens L. we have obtained $21.2574 \mathrm{~g}$ of the extract of the leaves in ethanol (EEFCF), which has resulted in a yield of $8.77 \%$. As for the $C$. limonium, we have obtained 36,8715 of ethanol extract (EEFCL), resulting in a yield of $8.19 \%$. These extracts have been submitted to a phytochemical study in order to identify the classes of the secondary metabolites, whose results can be observed in Table 3.

Table 3: Identification of the secondary metabolites present in the extract in ethanol of $C$. limonium and $C$. frutescens $\mathrm{L}$.

\begin{tabular}{ccc}
\hline SECONDARY METABOLITES & EEFCL & EEFCF \\
\hline Phenols and Tanines & Tanines (+) & $(-)$ \\
Anthocyanines, Anthocyanidines and Flavanoids & Presence of & $(-)$ \\
Flavanols, Flavanones, Flavanonols and Xanthones & Flavones, Flavanols & \\
Leucoanthocyadinin, Catechins and Flavones & $(-)$ & $(-)$ \\
Saponins & $*$ & $(-)$ \\
Steroids and Triterpenoids & $(+)$ & $(-)$ \\
& Presence of free & Presence of free \\
\end{tabular}

EEFCL:Extract in ethanol of the Citrus Limonium leaves

EEFCF:Extract in ethanol of the Capsicum frutescens L. leaves

$(-)$ : negative test

$(+)$ : positive test

$*$ :test not performed

In the phytochemical analysis, the test for the extract in ethanol of the $C$. limonium has demonstrated the presence of condensed tannins, saponins and free steroids, but flavanols, flavanonols and/or xanthones have not been found. As for the $C$. frutescens L., only the presence of free steroids has been registered. 
In the fractioning of the extracts in ethanol, the renderings of the fractions can be observed on Table 4.

Table 4: Rendering of the fractions obtained through the extracts of $C$. frutescensL. and $C$. limonium in ethanol

\begin{tabular}{lcccc} 
& \multicolumn{2}{c}{ Extract of C. frutescens L in ethanol } & \multicolumn{2}{c}{ Extract of C. limonium in ethanol } \\
\hline Fraction & Rendering & Code & Rendering & Code \\
\hline In Hexane & $19.47 \%$ & FHEEFCF & $0.12 \%$ & FHEEFCL \\
In Ethylacetate & $15.26 \%$ & FAEEFCF & $4.01 \%$ & FAEEFCL \\
In Methanol & $56.3 \%$ & FMEEFCF & $55.00 \%$ & FMEEFCL \\
\hline
\end{tabular}

FHEEFCFFraction in hexane of the ethanol extract in the leaves of $C$. frutescens $L$;

FAEEFCFFraction in ethylacetate of the ethanol extract in the leaves of $C$. frutescens $L$;

FMEEFCFFraction in methanol of the ethanol extract in the leaves of $C$. frutescens $L$;

FHEEFCLFraction in hexane of the ethanol extract in the leaves of $C$. limonium;

FAEEFCLFraction in ethylacetate of the ethanol extract in the leaves of $C$. limonium

FMEEFCLFraction in methanol of the ethanol extract in the leaves of $C$. limonium;

In order to verify the classes of the secondary metabolites in the fractions obtained through the extracts of both plants, we have performed phytochemical tests. The results obtained can be observed on Tables 5 and 6 .

Table 5: Identification of the secondary metabolites present in the fractions obtained from the extract of $C$. limonium in ethanol

\begin{tabular}{|c|c|c|c|}
\hline SECONDARY METABOLITES & FHEEFCL & FAEEFCL & FMEEFCL \\
\hline Phenols and Tanines & $(-)$ & $(-)$ & $(-)$ \\
\hline $\begin{array}{l}\text { Anthocyanines, Anthocyanidines } \\
\text { and Flavanoids }\end{array}$ & $(-)$ & $\begin{array}{c}\text { Flavones, Flavonols } \\
\text { and Xanthones }\end{array}$ & $\begin{array}{c}\text { Flavones, Flavonols } \\
\text { and Xanthones }\end{array}$ \\
\hline $\begin{array}{l}\text { Flavanols, Flavanones, } \\
\text { Flavanonols and Xanthones }\end{array}$ & $(-)$ & $(-)$ & $(-)$ \\
\hline Saponins & $(+)$ & $(+)$ & $(+)$ \\
\hline Steroids and Triterpenoids & $(-)$ & Free steroids & Free steroids \\
\hline
\end{tabular}

With the fractioning of the vegetable extracts, there was a separation of the secondary metabolites present in them, and with the fractioning of these we could analyze to what fraction they were actually present. On Table 5 , it was possible to observe that all the fractions of $C$. limonium were positive for saponins; as for the fractions of ethylacetate and methanol have indicated the presence of flavones, flavanols and Xanthones and free steroids, while the others tested negative.

Table 5: Identification of the secondary metabolites present in the fractions in ethanol of the leaves of C. frutescens $\mathrm{L}$.

\begin{tabular}{lccc}
\hline \multicolumn{1}{c}{ SECONDARY METABOLITES } & FHEEFCF & FAEEFCF & FMEEFCF \\
\hline Phenols and Tanines & $(-)$ & $(-)$ & $(-)$ \\
Anthocyanines, Anthocyanidines and Flavanoids & $\begin{array}{c}\text { Flavones, Flavonols } \\
\text { and Xanthones }\end{array}$ & $\begin{array}{c}\text { Flavones, Flavonols } \\
\text { and Xanthones }\end{array}$ & $(-)$ \\
Leucoanthocyadinin, Catechins and Flavones & $(-)$ & $(-)$ & $(-)$ \\
Flavanols, Flavanones, Flavanonols and Xanthones & $(-)$ & $(-)$ & $(-)$ \\
Saponins & $(-)$ & $(-)$ & $(+)$ \\
Steroids and Triterpenoids & $(-)$ & Free steroids & Free steroids \\
\hline
\end{tabular}

FHEEFCFFraction in hexane of the ethanol extract in the leaves of $C$. frutescens $L$; FAEEFCFFraction in ethylacetate of the ethanol extract in the leaves of $C$. frutescens $L$; FMEEFCFFraction in methanol of the ethanol extract in the leaves of $C$. frutescens $L$; 
On Table 5, we can verify that the fractions containing hexanol and ethylacetate of $C$. frutescens $L$. have indicated the presence of flavones, flavanols and xanthones, while the one containing methanol tested positive for saponins and the fractions containing ethylacetate and methanol have registered free steroids.

In order to define the necessary concentration to inhibit the radical DPPH in 50\%, we have calculated the inhitibiting concentration $\left(\mathrm{Cl}_{50}\right)$. On Table 6 , we have registered the results of the antioxidant tests for all samples.

Table 6: Antioxidant activity obtained by the method DPPH of the extracts and fractions of the leaves of $C$. frutescens $\mathrm{L}$. and C. limonium.

\begin{tabular}{lcccc} 
& \multicolumn{2}{c}{ Capsicum frutescensL. } & \multicolumn{2}{c}{ Citrus limonium } \\
\cline { 2 - 5 } Extract/Fraction & $\mathrm{Cl}_{\mathbf{5 0}}$ & Code & Cl $_{\mathbf{5 0}}$ & Code \\
\hline In Ethanol & $204.60 \mathrm{ppm}$ & EEFCF & $99,07 \mathrm{ppm}$ & $\mathrm{EEFCL}$ \\
In Hexane & $387.08 \mathrm{ppm}$ & FHEEFCF & - & $\mathrm{FHEEFCL}$ \\
In Ethylacetate & $251.62 \mathrm{ppm}$ & FAEEFCF & $300 \mathrm{ppm}$ & $\mathrm{FAEEFCL}$ \\
In Methanol & $253.59 \mathrm{ppm}$ & FMEEFCF & $136.60 \mathrm{ppm}$ & $\mathrm{FMEEFCL}$ \\
TROLOX & $4.07 \mathrm{ppm}$ & - & $4.07 \mathrm{ppm}$ & - \\
\hline
\end{tabular}

EEFCF: Extract in ethanol of the Capsicum frutescens $L$. leaves

FHEEFCFFraction in hexane of the ethanol extract in the leaves of $C$. frutescens $L$;

FAEEFCFFraction in ethylacetate of the ethanol extract in the leaves of $C$. frutescens $L$;

FMEEFCFFraction in methanol of the ethanol extract in the leaves of $C$. frutescens $L$;

EEFCL:Extract in ethanol of the Citrus Limonium leaves

FHEEFCLFraction in hexane of the ethanol extract in the leaves of $C$. limonium;

FAEEFCLFraction in ethylacetate of the ethanol extract in the leaves of $C$. limonium;

FMEEFCLFraction in methanol of the ethanol extract in the leaves of $C$. limonium;

According to what has been observed, we can notice that the fractions of Capsicum frutescens L. andCitrus limonium do not present a goot antioxidant activity, the extract thathas indicated a better activity whencompared to TROLOX, using a positive pattern, was the ethanol extract in both plants. Thus suggesting that for the antioxidant activity is more viable for the extract in which there is a sinnergic action of the secondary metabolites present.

On Table 7, it is possible to observe the result of the content of the total phenols of the fractions, which have been performed accroding to the method proposed by Folin-Ciocalteau and were expressed in equivalence to gallic acid (EGA) by fram of gross extract.

Table 7: Content of total phenols obtained by the Folin-Ciocalteau method of the extracts and fractions of the leaves of $C$. frutescens $L$. and $C$. limonium.

\begin{tabular}{lcccc} 
& \multicolumn{2}{c}{ Capsicum frutescens $L}$. & \multicolumn{2}{c}{ Citrus limonium } \\
\cline { 2 - 5 } Extract/Fraction & $\begin{array}{c}\text { TOTAL PHENOLS } \\
\text { (md/EGA of gross } \\
\text { extract) }\end{array}$ & Code & $\begin{array}{c}\text { TOTAL PHENOLS } \\
\text { (md/EGA of gross } \\
\text { extract) }\end{array}$ & Code \\
\hline In Ethanol & 34.96 & EEFCF & 40.22 & EEFCL \\
In Hexane & 54.25 & FHEEFCF & - & FHEEFCL \\
In Ethylacetate & 16.53 & FAEEFCF & 16.53 & FAEEFCL \\
In Methanol & 6.88 & FMEEFCF & 27.06 & FMEEFCL \\
\hline
\end{tabular}

EEFCF: Extract in ethanol in the leaves of Capsicum frutescens $\mathrm{L}$.

FHEEFCFFraction in hexane of the ethanol extract in the leaves of $C$. frutescens $L$;

FAEEFCFFraction in ethylacetate of the ethanol extract in the leaves of $C$. frutescens $L$;

FMEEFCFFraction in methanol of the ethanol extract in the leaves of $C$. frutescens $L$;

EEFCL:Extract in ethanol in the leaves of C.Limonium

FHEEFCLFraction in hexane of the ethanol extract in the leaves of $C$. limonium;

FAEEFCLFraction in ethylacetate of the ethanol extract in the leaves of $C$. limonium;

FMEEFCLFraction in methanol of the ethanol extract in the leaves of $C$. limonium; 
As is well known, the antioxidant activity is closely related to the content of phenols, once the phenolic compounds are included in the classification of antioxidants.So being, when analysing Tables 6 and 7, we can observe that this relation has only been proved for the $C$. limonium, since the ethanol extract has presented a better antioxidant activity and has also presented the highest content of total phenols. As for the $C$. frutescens $L$., it is possible to observe an inverse relation, which was not meant to occur once the phenols are good antioxidants; however, there may occur false positives, which points the influence of some factors in the results, such as: absence of tanines, non-significant presence of flavonoids (SANTOS; BLATT, 1998) and the presence of proteins (SILVA et al, 2010).

\section{CONCLUSION}

According to the studies, observations and experiments, we have registered as results the presence of flavones, flavanols and xanthones, free steroids and saponins for the Citrus limonium; as for the Capsicum frutescens $L$. we have registered the presence of flavones, flavanols and xanthones, saponins and free steroids, which are characterized dor being secondary metabolites.

As for the antioxidant activity of the Capsicum frutescens L., when compared to the positive pattern, it is considered low, presenting a very high $\mathrm{IC}_{50}$, where the extract of the leaves in ethanol was the one that presented the best antioxidant activity as well as a low value of total phenols.

The antioxidant activity of the $C$. limonium, when compared to positive patters such as the TROLOX, which has been used as part of this study, has not been good, for it has presented high $\mathrm{Cl}_{50}$, the extract that has presented a better activity was the one in ethanol. The plant has presented a considerable content of total phenols in the composition of its extracts; however, when compared to the activity of the extract of the leaves of $C$. frutescens $L$. we can observe the first one stands out for having a lower content of $\mathrm{Cl}_{50}$.

\section{REFERENCES}

1. BARROSO, G. M. Sistemática de Angiospermas do Brasil. v.2. Imprensa Universitária, Universidade Federal de Viçosa, Viçosa. 1986.

2. BONOLI, M.; VERARDO, V.; MARCONI, E.; CABONI, M. F Antioxidant Phenols in Barley (Hordeum vulgare L.) Flour: Comparative Spectrophotometric Study Among Extraction Methods of Free and Bound Phenolic Compounds. Journal of Agricultural and Food Chemistry. v. 52, p. 5195-5200, 2004.

3. BRAND-WILLIAMS, W.; CUVELIER, M. E.; BERSET, C. Use of a free radical method to evaluate antioxidant activity. Lebensmittel - Wissenschaft Technologie. v. 28, n. 1, p. 25-30, 1995.

4. CALIXTO, J. B. Twenty-five years of research on medicinal plants in Latin America: a personal review. Journal Ethnofarmacology. v. 100, p. 131-134, 2005.

5. CARVALHO, J. E. Fitoterápicos: Alimento ou Medicamento? In: MERCADANTE, A. Z.; BOBBIO, F. O.; BOBBIO, P. A.; PEREIRA, J. L.; PASTORE, G. M., ed. Ciência de Alimentos: avanços e perspectivas vol II. Faculdade de Engenharia de Alimentos da Unicamp, Campinas, 196-202, 
2001.

6. DIMITRIOS, B. Sources of natural phenolics antioxidants. Trends in Food Science \& Technology. v. 17, n. 9, p. 505-512, 2006.

7. ECONOMOS, C.; CLAY, W. D. Nutritional and health benefits of citrus fruits. Food, Nutrition and Agriculture. v. 24, n. 1, p. 8-11, 1999.

8. MATOS, E. H. S. F. Dossiê Tecnico: Cultivo de limão. Centro de Apoio ao Desenvolvimento Tecnológico da Universidade de Brasília - CDT/UnB. 2007.

9. MATOS, F. J. A. Introdução a fitoquímica experimental. 3 ed. - Fortaleza: Edições UFC, p. 4754, 2009.

10. REIFSCHNEIDER, F. J. B. (Org.) Capsicum: pimentas e pimentões no Brasil. Brasília: Embrapa Comunicação para Transferência de Tecnologia/Embrapa Hortaliças, 2000.

11. SANTOS, M. D.; BLATT, C. T. T. Teor de flavonóides e fenóis totais em folhas de Pyrostegia venusta miers de mata e de cerrado. Revista Brasileira de Botânica. v. 21, n. 2, São Paulo, ago. 1998.

12. SILVA, M.L.C.; COSTA, R.S.; SANTANA, A. S.; KOBLITZ, M. G. B. Compostos fenólicos, carotenóides e atividade antioxidante em produtos vegetais. Semina: Ciências Agrárias, Londrina, v. 31, n. 3, p. 669-682, jul./set. 2010.

13. VEIGA JUNIOR, V.F.; MELLO. J. C. P. As monografias sobre plantas medicinais. Revista Brasileira de Farmacognosia. v. 18, p. 464-471, 2008. 